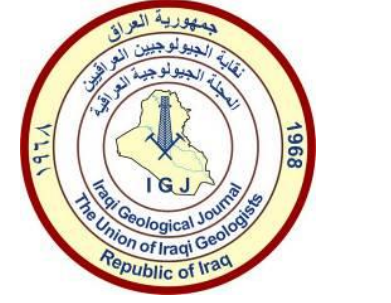

Iraqi Geological Journal

Journal homepage: https://www.igj-iraq.org

\title{
Some Engineering Properties of Ancient Fire Clay Bricks Discovered at the Dilbat Archaeological Site, South of Hilla City
}

\author{
Ghadeer Ahmed Abed ${ }^{1, *}$, Jwad Kadhim Manii ${ }^{1}$ and Jaffar Hussain Ali ${ }^{1}$ \\ Department of Applied Geology, College of Science, University of Babylon, Babylon, Iraq \\ Correspondence: ghado496@gmail.com
}

\begin{abstract}
Received:

5 October 2021

In this research, some engineering properties were studied for samples of fire clay bricks,

Accepted:

23 November 2021 which were selected from the study area, Dilbat or Tel al-Deylam, which dates back to the Middle Babylonian era 1500-600 BC in the southern part of the province of Babylon within the Al-Kifl district. The samples taken were subjected to many Engineering tests, which is the ratio of porosity, compressibility, density and ultrasound examination ( $\mathrm{Vp}, \mathrm{Vs}$ ), from

Published:

28 February 2022 which each of Young's modulus, Poisson's modulus, Bulk modulus, Shear modulus was extracted, where the average porosity (23.06) which ranges (27.30-18.53), density (1.09) ranges (1.52-0.89), water absorption (20.86) ranges (26.17-15.94), compressibility (5.10) ranges (9.96-3.31), Vp (1053) ranges (2410-350),Vs (737.1) ranges (1687-245), Young's modulus (1.89) ranges (8.82-0.11), Poisson's modulus (0.013) ranges (0.013-0.013), Bulk modulus (1.89) ranges (8.82-0.11), Shear modulus ( 0.92) ranges (4.32-0.05).
\end{abstract}

Keywords: Dilbat; Tel Al-Deylam; Engineering properties; Bricks; Ancient Mesopotamia

\section{Introduction}

Settlement in ancient Mesopotamia was characterized by huge cities in which the greatest kings and large numbers of people lived, as well as the priests of the temples and the gods that those people played. From the end of the Uruk era until the end of the Old Babylonian period (1500-3500) BC. The cultural landmarks in Mesopotamia were very impressive patterns that amazed archaeologists and researchers in terms of the huge advanced architecture of temples, buildings and palaces with impressive artistic forms and administrative organization. Through these remaining material effects from previous times, an image of political and social institutions and their role in managing society at that time was formed, as they maintained the cohesion of society within cities among the various members of society. Without these institutions, society is divided and conflicts that are difficult to solve. There were different patterns of settlement in Mesopotamia, while other societies in many parts of the world lived at the village level, which is defined by the frequent division of settlement. The development of this society was not an accident, but rather the outcome of many life, political, social and economic experiences that these societies went through. With the development of cities, areas arose that had a special significance in the life of society, which had a connection with gods, kings and other events. Therefore, many major cities during the third and fourth millennium BC are still being rebuilt, restored, and settled by residents.

DOI: $10.46717 /$ igj.55.1B.12Ms-2022-02-28 
(Ur, 2013). Mesopotamia, especially ancient Babylon and Sumer, meaning the central and southern part of Iraq, is one of the most important citizens in which civilization was formed, as it is the beginning of developments in the various fields that led to the formation of urban society. Agriculture, which provided a way of life as a kind of self-sufficiency for society, as well as multiple industries, religious beliefs, and various strata of society had begun in Mesopotamia. One of the most important achievements of Mesopotamia is writing, which is considered one of the most important pillars through which we preserved our ancient history and shared with us the details of our past with various peoples in the present. Despite this, Mesopotamia was not the only country at that time that invented these developments, but it was the first. (Foster et al., 2011) Ancient relics, cuneiform texts and other artifacts of Mesopotamia constitute a major source of information about the former peoples and their way of life, as it is one of the most reliable sources. Through the discovered archeology, we have an idea of how the cultural, urban and political development has evolved over time. (Mcintosh, 2005). The first excavations carried out in Tell Al- Deylam were by Hormuzd Rassam for the British Museum in 1897 AD. Through his study of some of the tablets found by the local population, it became clear to him that Tell al-Deylam is the remnants of the ancient city of Dilbat, and on its track he carried out excavations in the hill, which were not scientific, but for the purpose of searching for artifacts and cuneiform tablets. After that, the most important excavations of Tell Daylam were carried out by James Armstrong in 1989-1990 AD for the benefit of the University of Chicago, USA. Where three sensors A, B, and C were excavated, the most important of which was the probe $\mathrm{B}$, which represents the architectural legacy, Where the remains of houses from the ancient Babylonian era were discovered, as well as tombs, several pottery vessels and kilns of these pottery vessels, which date back to the late seventeenth and eighteenth centuries. Due to the sporadic results, it has not been possible until now to create a comprehensive map of the city, which means that data related to population density and the size of the city is not possible until further notice. (Wenger, 2012)

The city of Dilbat is a significant part of Babylon history and its great civilization, it represents the remains of an ancient temple of the god Urash the god of agriculture and war and he is the local god and protector of the city and his wife, the goddess Nin Gal, and it is worth noting that the god Urash was mentioned in the cuneiform texts with two genus sometimes as male and other as female. This city has great importance to the Babylonians, as they called one of the eight gates on the inner walls of the city of Babylon the name of the gate of the god Urash, perhaps this name intended because it is the gate that overlooks the city of Dilbat (Moses et al., 2019) Dilbat or Tel al-Daylam (Fig. 1) is located in Babil Governorate, in the district of Kifl, district (5) Abu Samij, in a plain area confined between Shatt AlHilla on one side and Shatt Al-Hindiya (the current Euphrates) on the other side, and it is located 30 $\mathrm{km}$ south of the ancient city of Babylon (the ruins of Babylon), and it is only $25 \mathrm{~km}$ away from the city of hilla the capital of Babil Governorate, while it is $15 \mathrm{~km}$ southeast of Perss Nimrud, the remains of the ancient city of Borsippa. Dilbat occupies an area of more than 150 dunums. The height of the hill above the level of the adjacent plain is about 6.5 meters; its current boundaries are represented by the presence of two irrigation channels split from the Majariah River at the end of the seventies of the last century, bordering it from the north and west. on the eastern side, it is bordered by a group of fields and orchards. As for the south, it is bordered by Apaved Street. (Moses et al., 2019).

Public buildings such as temples are often identified in the archaeological record by special criteria in construction such as decoration, size, building materials, and location, in addition to the inscriptions and writings that may be found on the walls of the buildings. The widespread presence of temples at that time indicates the interest of the ancient society in religious duties through the appointment of representatives to take care of these affairs and organize them.(Crawford, 2013) The temples in Mesopotamia have gone through many developments in construction engineering through different ages, starting with very simple forms, as in the temple located in the city of Eridu in southern Mesopotamia, which dates back to $5000 \mathrm{BC}$ then the forms of the temples changed in about $4000 \mathrm{BC}$ 
and there were an increase in the area of temples. In later periods in the empires of Babylon and Assyria, changes also took place, including merging the temple with the palace structure. (Bertman, 2003) there are two types of temples in Mesopotamia: the ground temple and the ziggurat, and there are several differences between these two types in terms of shape and purpose. The ground temple is built on flat ground and is next to the ziggurats if found. As for the ziggurat, it is a high, terraced building with several layers, where the lower layers are larger than the upper layers, and the number of these layers ranges from 3 to 8 depending on the city in which the ziggurat is located. It also contains a temple at its top and is built of solid mud bricks. (Kuiper, 2010)

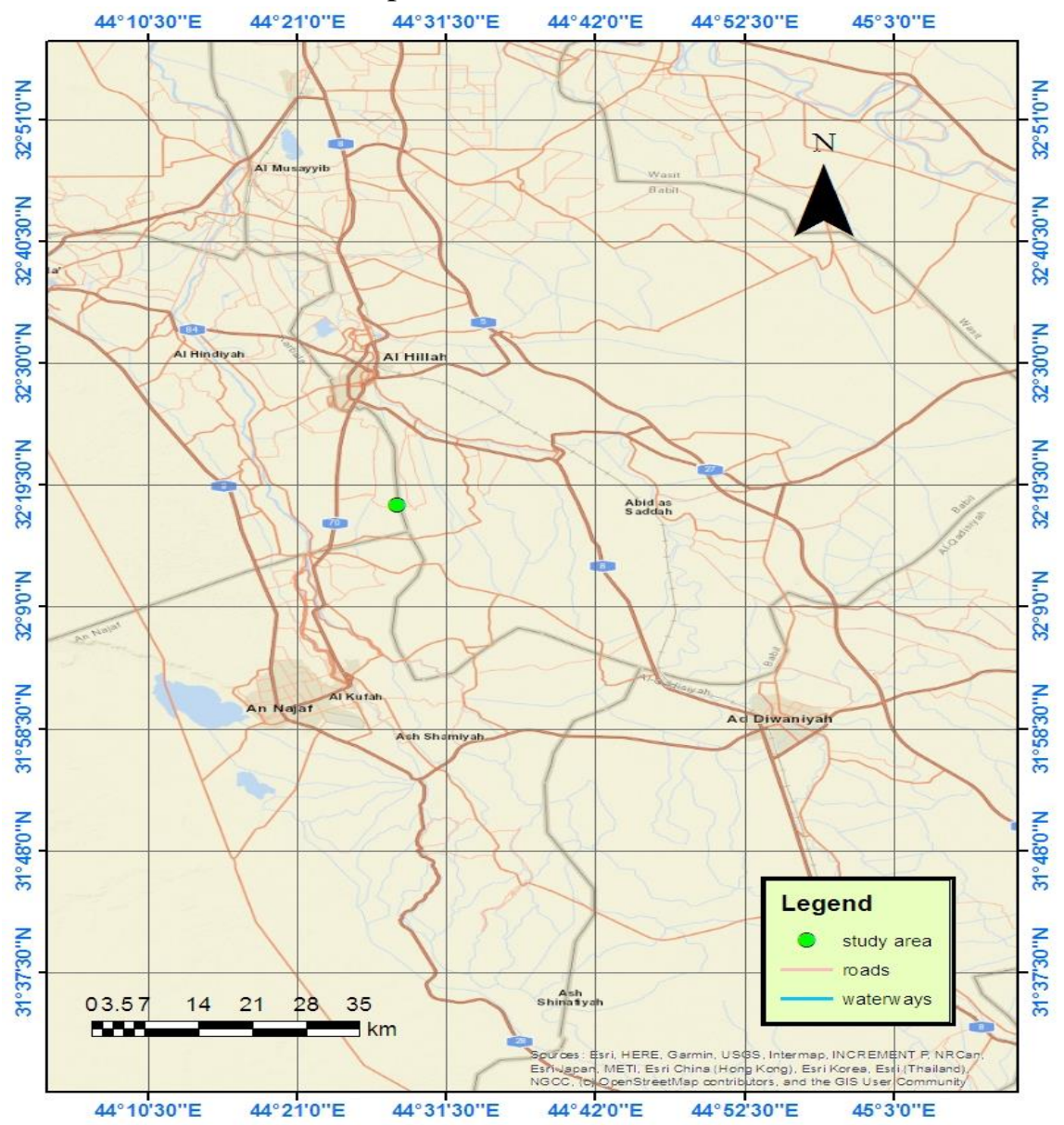

Fig. 1. A map for study area

\section{Materials and Methods}

\subsection{Physical Tests}

The physical tests include bulk density, porosity and water absorption according to ASTM D2487-11. (2011).

\subsubsection{Bulk density}

Brick density is an important parameter. We can calculate the bulk density by dividing the mass by volume. (Campbell \& Henshall, 2008)

$$
\text { Bulk Density }=\frac{\text { mass }}{\text { volume }}
$$

The units of Bulk Density are $\mathrm{kg} / \mathrm{m}^{3}$ or $\mathrm{lb} / \mathrm{ft}^{3}$ 


$$
\text { Bulk Density }=\frac{\mathrm{W}_{0}}{\mathrm{~B}_{\mathrm{v}}}
$$

Where; $\mathrm{W}_{0}=$ dry sample weight, $\mathrm{B}_{\mathrm{V}}=$ total sample volume

\subsubsection{Porosity}

The definition of porosity in general is in the form of the ratio of the volume of the gaps or voids within the sample to the total volume of the sample and the symbol (n) refers to the porosity. The porosity ratio is measured from the equations below: (Duggal, 2008)

$$
\begin{aligned}
& \mathrm{n} \%=\left[\frac{\mathrm{w}_{3}-\mathrm{w}_{1}}{\mathrm{w}_{3}-\mathrm{w}_{2}}\right] \times 100 \\
& \mathrm{n} \%=\left[\frac{\mathrm{V}_{\mathrm{v}}}{\mathrm{V}_{\mathrm{t}}}\right] \times 100
\end{aligned}
$$

While; $\mathrm{n}=$ porosity $(\%), \mathrm{W}_{1}=$ dry sample weight $(\mathrm{gm}), \mathrm{W}_{2}=$ weight of the saturated sample immersed in oil $(\mathrm{gm}), \mathrm{W}_{3}=$ weight of the oil-saturated sample $(\mathrm{gm}), \mathrm{Vv}=$ void volume, $\left(\mathrm{w}_{1}-\mathrm{w}_{3}\right)$ $\left(\mathrm{cm}^{2}\right), \mathrm{Vt}=$ total volume, $=\left(\mathrm{w}_{2}-\mathrm{w}_{3}\right)\left(\mathrm{cm}^{2}\right)$. The presence of pores in rocks and other materials depends on the shape and size of the crystals or grains that make up the sample or rock, as well as the degree of gradation of these grains, how they are stacked and arranged, and the type of bonding material (Hussein, 2010). Porosity is one of the most important properties that affect the mechanical and physical properties of a rock or sample, such as durability (Sabatakakis et al., 2008). Porosity affects the quality of bricks and is considered one of the important factors because it affects many properties of bricks such as durability and mechanical strength. Old bricks contain high values of porosity that may reach about 15$40 \%$ of the volume of bricks (Fernandes et al., 2010).

The quality of the raw materials used to produce Bricks such as clay and straw as well as the added amount of water and the degree of burning of the bricks will greatly affect the distribution and size of the pores. There is a relationship between the temperature of burning bricks and the pores. The higher the burning temperatures, the larger the pores will increase, which reach about 3-15 micrometers, and the contact of these pores will be little, while the small pores will reduce their percentage. Studies have shown that large pores are better than small ones because less affected by the cycles of thawing and freezing, as well as soluble salts. The small pores (1 micron or less) in the bricks result from the presence of some low-quality materials in the clay such as carbon, as well as from burning bricks at a temperature of (800-1000) degrees Celsius. In general, these pores in bricks have negative effects such as decreasing the durability and quality of bricks. (Fernandes et al., 2010). The porosity values depend on the size, shape of grains, mineral crystals, degree of grading and the nature of packing (Sabatakakis, et al., 2008).

\subsubsection{Water Absorption}

Absorption is defined as the percentage of absorbed water that occupies in the bricks through its pores. It is also defined as the percentage of the absorbed water weight to the total weight of the sample (brick) (Al-Saad, 2014). The following specification was adopted ASTM C20-00, 2010) according to the following:

$$
\mathrm{W} . \mathrm{A} \%=\frac{\mathrm{W}_{2}-\mathrm{W}_{0}}{\mathrm{~W}_{0}} \times 10
$$

Where; W.A\% = percentage of water absorption; $\mathrm{W}_{2}=$ Weight of the sample saturated with water $(\mathrm{g}) ; \mathrm{W}_{0}=$ Weight of the dry sample $(\mathrm{g})$. 


\subsection{Engineering Test of Bricks in Study Area}

Ultrasonic method is one of the non-destructive techniques that are important in describing building materials, especially those that are related to the archaeological and historical field, due to the need to preserve them as a heritage. Other advantages of non-destructive measurements are that they can be performed within a short period of time and with remarkable ease. This technique is used as one of the most common methods for examining mortar, concrete, building materials and wood by knowing their mechanical properties such as the modulus of elasticity as well as examining the homogeneity of the material and the compressive strength. The waves are generally divided into two main types: mechanical waves and electromagnetic waves. Ultrasonic waves are considered among the mechanical waves because this type of waves requires a physical environment for the purpose of its propagation and thus to transmit that energy. It is also possible to divide mechanical waves into two parts: surface waves and body waves. Body waves include $\mathrm{P}$ waves or those called longitudinal waves, which are waves Compressive waves, as well as $\mathrm{S}$ waves or transverse waves, which are vibrational waves. As for surface waves, they are those waves whose motion on the surface of the Earth includes Rayleigh waves and Love waves. The longitudinal $\mathrm{P}$ and $\mathrm{S}$ transverse mechanical waves can propagate at different speeds independently of each other inside solid materials that are homogeneous. This test depends mainly on the measurement of the length of time it takes for ultrasonic waves to travel from one point to another through a specific medium or substance (Fig. 2) (Araújo et al., 2020).

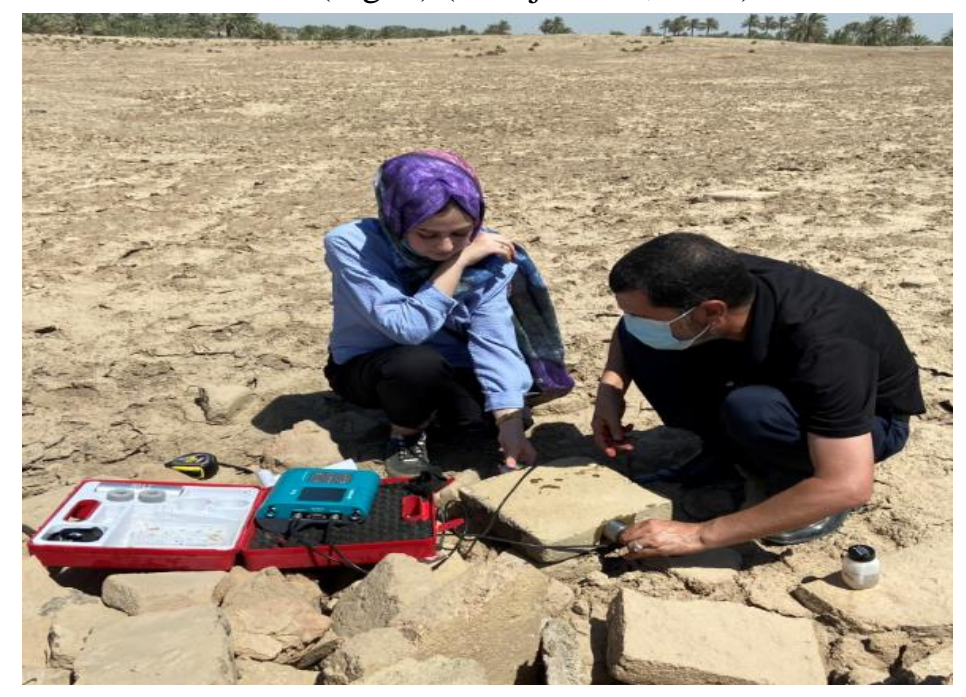

Fig. 2. Above illustrates the ultrasonic device used in the study area

The value of the longitudinal waves Vp was measured and through it the transverse waves Vs were calculated according to the equation (6): (Araújo et al., 2020)

$$
\mathrm{V}_{\mathrm{s}}=0.7 \times \mathrm{V}_{\mathrm{p}}
$$

Through the relationship between the $\mathrm{Vp} \& \mathrm{Vs}$, the following modulus were calculated, poisson's ratio $(\mu)$ as in the following equation: (Araújo et al., 2020).

$$
\mu=\frac{V_{p}^{2}-2 V_{s}^{2}}{2 V_{p}^{2}-V_{s}^{2}}
$$

Young's modulus (E): as in the following equation: (Araújo et al., 2020)

$$
\mathrm{E}=\frac{\rho \times \mathrm{V}_{\mathrm{p}}^{2}(1+\mu)(1-2 \mu)}{(1-\mu)}
$$

While $\rho$ is density can be calculated according to the following equation: (Araújo et al., 2020): 


$$
\rho=\frac{\mathrm{m}}{\mathrm{V}}
$$

Where; $m=$ weight of sample; $v=$ volume of sample.

Shear modulus $(\mathrm{G})$ : as in following equation: (Araújo et al., 2020)

$$
\mathrm{G}=\rho \times \mathrm{V}_{\mathrm{s}}^{2}
$$

Bulk modulus or Incompressibility (K): as in following equation: (Araújo et al., 2020)

$$
\mathrm{K}=\rho \times \mathrm{V}_{\mathrm{p}}^{2}-\frac{4}{3} \mathrm{G}
$$

Therefore, the compressive strength $\left(\mathrm{F}_{\mathrm{c}}\right)$ of the bricks of the study area can be calculated according to the following equation: (Araújo et al., 2020)

$$
\mathrm{F}_{c}=2.7718 \times \mathrm{e}^{0.533 \times \mathrm{V}_{\mathrm{p}}}
$$

\section{Results}

The results of the physical and engineering tests for 10 samples of bricks in Dilbat city are shown in Tables 1 and 2 below:

Table1. The results of physical properties of Dilbat bricks

\begin{tabular}{lccc}
\hline Sample No. & Bulk density $\mathbf{g m} / \mathbf{c m}^{\mathbf{3}}$ & Porosity $\%$ & Water Absorption \\
\hline S1 & 1.12 & 24.61 & 22.10 \\
S2 & 1.03 & 27.30 & 26.17 \\
S3 & 0.89 & 18.53 & 15.94 \\
S4 & 0.94 & 20.14 & 18.22 \\
S5 & 1.52 & 27.26 & 25.72 \\
S6 & 1.35 & 26.15 & 23.45 \\
S7 & 0.93 & 19.24 & 16.80 \\
S8 & 1.24 & 25.17 & 22.38 \\
S9 & 0.90 & 19.87 & 17.15 \\
S10 & 0.98 & 22.40 & 20.68 \\
Average & 1.09 & 23.06 & 20.86 \\
Range & $1.52-0.89$ & $27.30-18.53$ & $26.17-15.94$ \\
\hline
\end{tabular}

The bulk density for Dilbat bricks (Table 1) ranging from the maximum value of (1.52) gm/ $\mathrm{cm} 3$ in (S5) to the minimum value $(0.89) \mathrm{gm} / \mathrm{cm} 3$ in the(S3) and the average is $(1.09) \mathrm{gm} / \mathrm{cm}^{3}$. The porosity for Dilbat bricks (Table 1) ranging from the maximum value of $27.30 \%$ in the $\mathrm{S} 2$ to the minimum value $(18.53 \%)$ in the $\mathrm{S} 3$ and the average is 23.06 . The water absorption for Dilbat bricks (Table 1) ranging from the maximum value of 26.17 in $\mathrm{S} 2$ to the minimum value (15.94) in the S3 and the average is 20.8 (Figs. 3, 4, 5, 6). 
Table 2. The results of engineering properties of Dilbat bricks

\begin{tabular}{lccccccc}
\hline $\begin{array}{l}\text { Sample } \\
\text { No. }\end{array}$ & $\begin{array}{c}\mathbf{V} \mathbf{p} \\
\mathbf{m} / \mathbf{s}\end{array}$ & $\begin{array}{c}\text { Vs } \\
\mathbf{m} / \mathbf{s}\end{array}$ & $\begin{array}{c}\text { Poisson's } \\
\text { ratio }(\boldsymbol{\mu})\end{array}$ & $\begin{array}{c}\text { Young's } \\
\text { modulus } \\
(\mathbf{E}) \mathbf{M p a}\end{array}$ & $\begin{array}{c}\text { Shear } \\
\text { modulus } \\
(\mathbf{G}) \mathbf{M p a}\end{array}$ & $\begin{array}{c}\text { Bulk } \\
\text { modulus } \\
(\mathbf{K}) \mathbf{M p a}\end{array}$ & $\begin{array}{c}\text { Compressibi } \\
\text { lity }(\mathbf{F c}) \\
\mathbf{N} / \mathbf{m m} \mathbf{2}^{2}\end{array}$ \\
\hline S1 & 1290 & 903 & 0.013 & 1.86 & 0.91 & 1.86 & 5.47 \\
S2 & 1050 & 735 & 0.013 & 1.13 & 0.55 & 1.13 & 4.80 \\
S3 & 350 & 245 & 0.013 & 0.11 & 0.05 & 0.11 & 3.31 \\
S4 & 650 & 455 & 0.013 & 0.40 & 0.19 & 0.40 & 3.89 \\
S5 & 2410 & 1687 & 0.013 & 8.82 & 4.32 & 8.82 & 9.96 \\
S6 & 1470 & 1029 & 0.013 & 2.91 & 1.42 & 2.91 & 6.04 \\
S7 & 560 & 392 & 0.013 & 0.29 & 0.14 & 0.29 & 3.70 \\
S8 & 1430 & 1001 & 0.013 & 2.53 & 1.24 & 2.53 & 5.92 \\
S9 & 520 & 364 & 0.013 & 0.24 & 0.11 & 0.24 & 3.63 \\
S10 & 800 & 560 & 0.013 & 0.62 & 0.31 & 0.62 & 4.21 \\
Average & 1053 & 737.1 & 0.013 & 1.89 & 0.92 & 1.89 & 5.10 \\
Range & $2410-350$ & $1687-245$ & $0.013-0.013$ & $8.82-0.11$ & $4.32-0.05$ & $8.82-0.11$ & $9.96-3.31$ \\
\hline
\end{tabular}

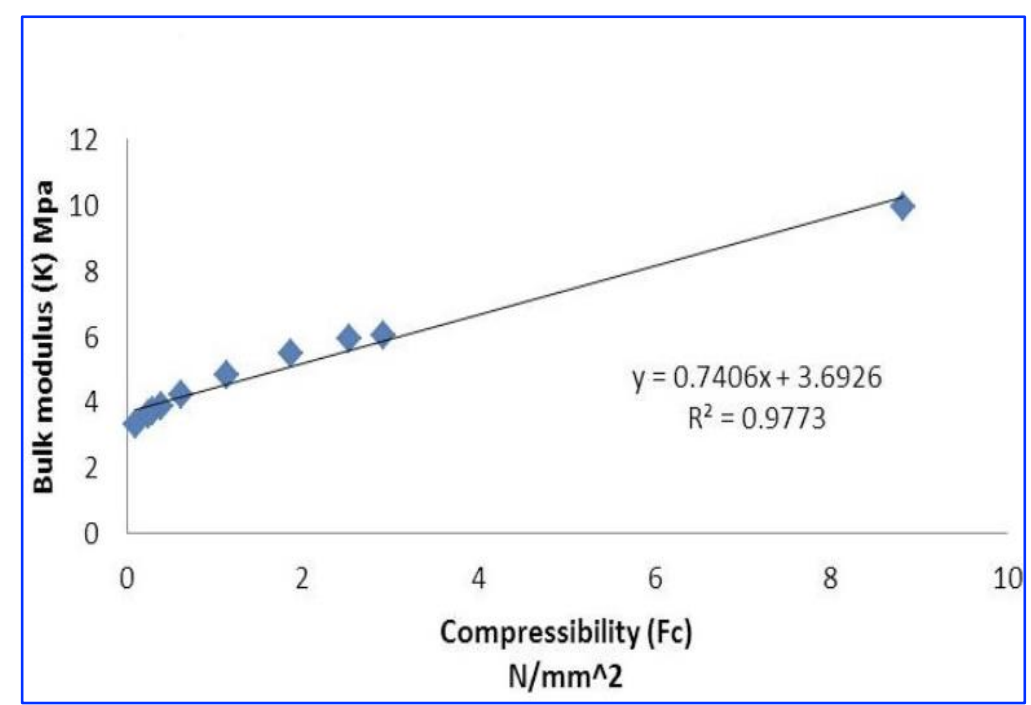

Fig. 3. Relationship between $\mathrm{K}$ and $\mathrm{Fc}$

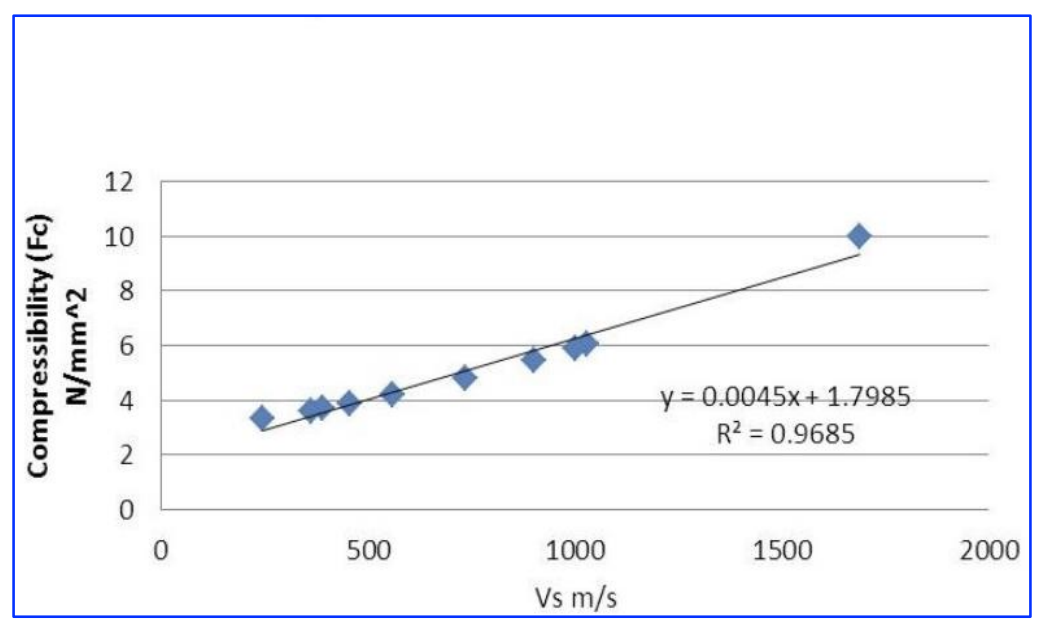

Fig. 4. Relationship between Vs and Fc 


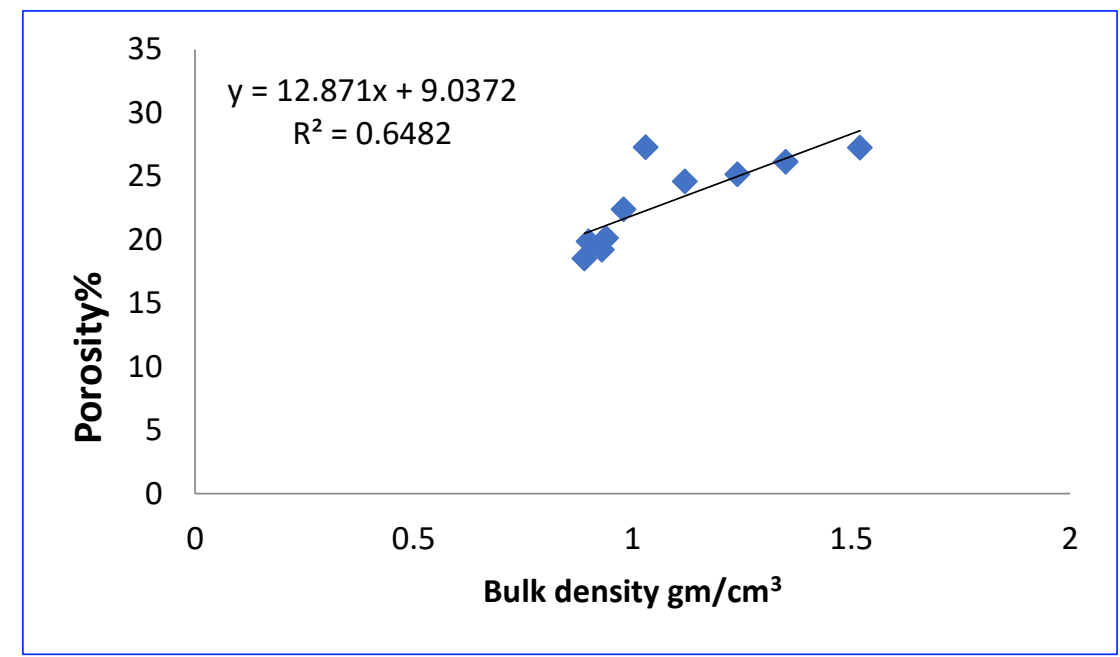

Fig. 5. Relationship between $\rho$ and n

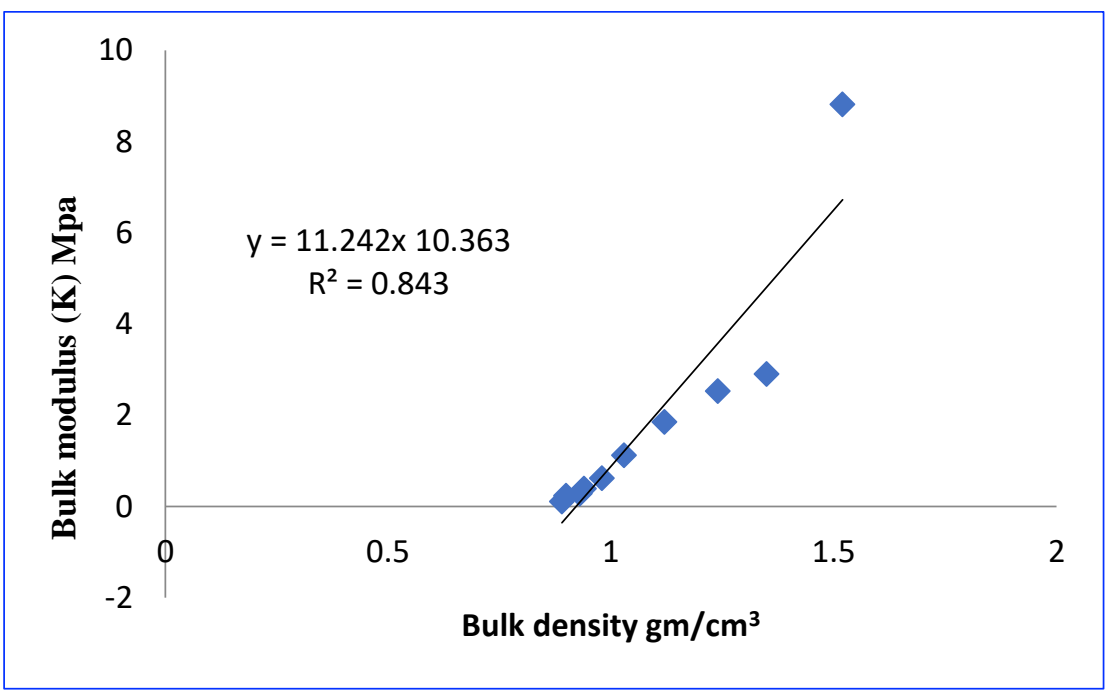

Fig. 6. Relationship between $\rho$ and $\mathrm{K}$

The Figs. 3,4,5,6 above show the relationship between the Bulk modulus (K) with Compressibility $(\mathrm{Fc})$, the Secondary waves (Vs) with Compressibility $(\mathrm{Fc})$, the Bulk density $(\rho)$ with Porosity $(\mathrm{n})$, the Bulk modulus $(\mathrm{K})$ with Bulk density $(\rho)$ as the relationship between $(\mathrm{Fc}-\mathrm{K}, \mathrm{Vs})$ is a good directive relationship ( $\mathrm{r}=0.977)(\mathrm{r}=0.968)$, also the relationship between $\rho-\mathrm{n}, \mathrm{K}$ is a good directive relationship $(\mathrm{r}=0.64),(\mathrm{r}=0.84)$.

From Table 2 the value of $\mathrm{Vp}$ for Dilbat bricks ranging from the maximum value of $2410 \mathrm{~m} / \mathrm{s}$ in $\mathrm{S} 5$ to the minimum value (350) in the (S3) and the average is $(1053) \mathrm{m} / \mathrm{s}$. The value of Vs for Dilbat bricks (Table 2) ranging from the maximum value of $1687 \mathrm{~m} / \mathrm{s}$ in $\mathrm{S} 5$ to the minimum value (245) in the S3 and the average is $737.1 \mathrm{~m} / \mathrm{s}$. Poisson's ratio for Dilbat bricks (Table 2) is 0.013 for all samples. Young's modulus ranging from the maximum value of $8.82 \mathrm{Mpa}$ in S5 to the minimum value $(0.11)$ $\mathrm{Mpa}$ in the $\mathrm{S} 3$ and the average is $1.89 \mathrm{Mpa}$. Shear modulus ranging from the maximum value of 4.32 Mpa in S5 to the minimum value (0.05) Mpa in the S3 and the average is $0.92 \mathrm{Mpa}$.

Bulk modulus ranging from the maximum value of $8.82 \mathrm{Mpa}$ in S5 to the minimum value $(0.11)$ $\mathrm{Mpa}$ in the $\mathrm{S} 3$ and the average is $1.89 \mathrm{Mpa}$ while Compressibility $(\mathrm{Fc})$ ranging from the maximum value of $9.96 \mathrm{Mpa}$ in S5 to the minimum value (3.31) Mpa in the S3 and the average is 5.10 Mpa. When comparing the results of the compressive strength of the bricks of the study area according to the Iraqi Standard Specification IQS 25-1993(Table 3) (ASTM C62-10, 2010) Table 4 shows that the bricks of 
the study area are a type of C according to IQS 25-1993 and a type of C according to (ASTM C62-10, 2010).

Table 3. The Iraqi Standard Specification (IQS 25-1993)

\begin{tabular}{lcc}
\hline Classes & $\begin{array}{c}\text { Minimum brick pressure } \\
\text { N/mm }\end{array}$ & $\begin{array}{c}\text { Maximum Absorption Percentage \% of } \\
\text { bricks }\end{array}$ \\
\hline A & 16 & 22 \\
A-10 bricks & 18 & 20 \\
B & 11 & 26 \\
B-10 bricks & 13 & 24 \\
C & 7 & 28 \\
C-10 bricks & 9 & 26 \\
\hline
\end{tabular}

Table 4. The ASTM C62-10, 2010

\begin{tabular}{ccc}
\hline \multirow{2}{*}{ Classes } & $\begin{array}{c}\text { Minimum brick pressure } \\
\mathrm{N} / \mathrm{mm}^{2}\end{array}$ & Maximum Absorption Percentage \% of bricks \\
\hline $\mathrm{A}$ & 17 & 20 \\
$\mathrm{~B}$ & 15 & 25 \\
$\mathrm{C}$ & 9 & - \\
\hline
\end{tabular}

\section{Conclusions}

Through the engineering and physical tests conducted on the bricks of the city of Dilbat, it was found that it is of class $\mathrm{C}$ and below, as a result of its exposure to weathering and erosion factors over long periods of time, and thus resulted in bricks with a relatively low compressive resistance, and it was found that the relationship between $\mathrm{Fc}-\mathrm{K}$, Vs is a directive relationship.

\section{Acknowledgements}

The authors are very grateful to the reviewers, Editor in Chief Prof. Dr. Salih M. Awadh, the Secretary of Journal Mr. Samir R. Hijab, and the Technical Editors for their great efforts and valuable comments.

\section{References}

Al-Saad, H. A. 2014. Mineral and geochemical information of clay rocks in selected areas east of Wasit and Maysanha for the manufacture of ordinary and light bricks, $\mathrm{PhD}$ thesis published, University of Basra, College of Science, 200.

Araújo, E., Sousa, I., Paz, R., Costa, C. H., \& Mesquita, E. 2020. Physical and mechanical characterization of traditional Brazilian clay bricks from different centuries. Journal of Building Pathology and Rehabilitation, 5(1), 1-12.

Bertman, S., 2003. Handbook to Life in Ancient Mesopotamia, Government and Society, temple, 191.

Campbell, D. J, \& Henshall, J. K. 2000. Bulk density. In Soil and Environmental Analysis, CRC Press, 327-360.

Duggal, S. K., 2008. Building Materials. New age international publishers, third revised edition, 52-83.

Fernandes, F. M., Lourenco, P. B., \& Castro, F. 2010. Ancient clay bricks: manufacture and properties. In materials, technologies and practice in historic heritage structures, Springer, Dordrecht, 29-48.

Foster, B. R., \& Karen, P. F. 2011. Civilizations of Ancient Iraq. Princeton University Press.

Hussein, S. A. 2010. A geochemical and petrophysical study to assess the navigation of limestone rocks for the purpose of cement industry in some of the holes formation in the Sukkari area, west of Baiji, Al-Iraqiya Journal of Science, 51(1), 122.

IQS 25-1993. Bricks made of clay bricks, the central device for carrying measurements, 1st floor, 5 .

Kuiper, K., 2010. Mesopotamia: the world's earliest civilization. Britannica Educational Publishing.

Mcintosh, J., 2005. Ancient Mesopotamia: new perspectives. ABC-C. 
Sabatakakis, N. K., Tsiambaos, G., \& Papanakli, S. 2008. Index properties and strength variation controlled by microstructure for sedimentary rocks, Engineering Geology, 97, 80-90.

Standard, A.S.T.M., D2487-11. 2011. Standard practice for classification of soils for engineering purpose (Unified Soil Classification System).

Standard, A.S.T.M., \& ASTM, P. 2010. C20-00. Standard test methods for apparent porosity, water absorption, apparent specific gravity, and bulk density of burned refractory brick and shape for boiling water.

Standard A.S.T.M., C62-10. 2010. Standard of specification for building brick (solid masonry unite made from clay or shale). American society for testing and material, PA, USA.

Ur, J. 2013. Patterns of settlement in Sumer and Akkad. The Sumerian World, 131-155.

Wenger, C. 2012. Städtische Anlagen des 2. vorchristlichen Jahrtausends in Mesopotamien (Doctoral dissertation, uniwien). 